\title{
POWERS IN TRUST AND THE TERMINATION OF POWERS BY THE DONEE ${ }^{1}$
}

\author{
LEWIS M. SIMIES
}

In its broader meaning a power may be described as the capacity to change legal relations. ${ }^{2}$ In this sense the law of powers is well nigh infinite in extent. The term is here employed in a more limited way, as it has been used in the law of Future Interests. For the purpose of this paper a power is the ability possessed by any person to extinguish legal relations in property, real or personal, and to create new legal relations therein, such power existing without regard to whether he has or has not other legal relations in the property concerned. Examples of such powers, which are commonly involved in the American decisions, are: the power of an executor to sell land as provided in the will; the power to appoint property, either to members of a class or without restriction; and the power given to a life tenant to sell for maintenance. Some types of powers will necessarily be excluded from this discussion, though within the definition stated, because the courts have not dealt with them in the same manner as the powers under consideration. Among these are the power of an agent to dispose of property, and powers created by statute, such as the powers of an assignee in bankruptcy, or of a sheriff, administrator or other officer, to dispose of property as provided by law.

The primary purpose of this paper is to propose the following as a statement of the American law: All powers are terminable by act of the donee except powers in trust. In view of the fact that the character of so-called powers in trust is a matter of some uncertainty, this discussion will consist of two parts. The first will consider the question: What is a power in trust?; the second: To what extent are powers terminable by act of the donee?

\section{POWERS IN TRUST}

An examination of cases, both English and American, discloses a frequent use of the terms "power in trust," "power in the nature of a trust," or "power coupled with a trust," in such vague and uncertain fashion as to leave the reader hopelessly at sea. It is believed, however, that the courts do recog-

${ }^{1}$ The writer desires to acknowledge the helpful suggestions he has received from Professors W. R. Vance and A. I. Corbin, of the Yale Law School, in the preparation of this paper.

2 See HoHFeld, Fundamental Legal Conceptions (1923) 50-60; Corbin, Legal Analysis and Terminology (1919) 29 Yare Law Jounsar 163. 
nize, with a fair degree of consistency, a definite concept which is termed a power in trust.

Before plunging into an analysis of the nature of a power in trust, it may be well, by way of illustration, to refer to a decision in which the character of this concept is directly involved. The West Virginia case of Milhollen's Adm'r $v$. Rice ${ }^{3}$ presents the common situation of a power to appoint to a class, where the donee died without making any appointment. A testator had left one half his real estate (in which he gave his wife a life interest) to be sold at her death, and had provided that the proceeds were to be disposed of "to whom she thinks proper of her heirs." The wife died without executing the power. In a bill by the administrator de bonis non to obtain a construction of the will it was held that the power of disposal conferred on the wife was a power in the nature of a trust; and that, therefore, the half interest in the proceeds of the land should go to her heirs to be equally distributed if more than one. Had not the power been given in trust, there would have been an intestacy on the death of the donee without exercising it. The discussion of the court is instructive. Three requisites were named as essential to the creation of a power in trust: first, there must be a certainty in the subject; second, there must be a certainty in the object; and, third, the power must be imperative. The court then explained the meaning of the term "imperative" in this connection, as follows:

"Its meaning as here used is that under the will it is his duty to exercise the power; and it is to be borne in mind that it is always his duty to carry out the intent of the testator, as shown by the will, no matter in what language that intent may have been expressed; and, if, therefore, the testator, either by express declaration, or fair implication, shows that he wishes the power he has given to be executed, it becomes the duty of the donee to execute such power; and such power is then regarded as imperative in the sense in which I have used the word."

This decision suggests the writer's mode of approach to the question: What is a power in trust? In this paper the subject will be discussed in the following order. First, we shall consider briefly what are the distinguishing marks of a power in trust. Second, having 'determined the marks by which a power in trust may be recognized, we shall endeavor to determine what legal consequences result from the existence of such a power,in other words, if we say with the West Virginia court that a power in trust is imperative, we shall then ask, does it make any difference whether it is or is not imperative. Most of the discussion will be directed to the question: What are the legal

8 13 W. Va. 510 (1878). 
consequences of the donee's failure to exercise a power in trust? For Part II of this paper is reserved the question: Does a power in trust differ from other powers with respect to the donee's ability to extinguish it?

The first question is not in doubt. Whatever may be the legal consequences involved, the distinguishing mark of a power in trust is that the donor intended it to be imperative. That is to say, the person who created the power intended that it should be exercised; he contemplated imposing upon the donee, not a mere privilege of exercising the power; but a duty to exercise it. In short, the legal conception of a power in trust involves a power plus a "duty." That this is the distinguishing mark of a power in trust has often been indicated by courts and by text writers." To quote the statement of Lord Eldon from Brovin $v$. Higgs ${ }^{5}$, so often repeated with approval in the cases:

"But there are not only a mere trust and a mere power, but there is also known to this Court a power, which the party, to whom it is given, is entrusted and required to execute; and with regard to that species of power the Court consider it as partaking so much of the nature and qualities of a trust that if the person who has that duty imposed upon him, does not discharge it, the Court will, to a certain extent, discharge the duty in his room and place."

But though a power in trust is always imperative, it may, and

4 That a power in trust is imperative was recognized in the following cases: Grieveson v. Kirsopp, 2 Keen 653 (1838); In re Hall [1899] 1 Ir. R. 308; Burrough v. Philcox, 5 Mry. \& Cr. 73 (1840); In re Brierley, 43 W'kly Rep. 36 (1894); Brook v. Brook, 3 Sm. \& G. 280 (1856); Brown v. Higgs, 8 Ves. 561 (1803); In re Weekes' Settlement [1897] $1 \mathrm{Ch}$. 289; In re Ilewellyn's Settlement [1921] $2 \mathrm{Ch}$. 281; In re Combe [1925] Ch. 210; Gorin v. Gordon, 38 Miss. 205 (1859); Cady v. Lincoln, 100 Miss 765, 57 So. 213 (1911) ; Greenough v. Welles, 10 Cush. 571 (Mrass. 1852); Dominicl: v. Sayre, 3 Sanf. 555 (N.Y. Super. 1850) ; Stoughton v. Liscomb, 39 R.I. 489, 98 Atl. 183 (1916); Milhollen's Adm'r v. Rice, supra note 3. See also People v. Kaiser, 306 Ill. 313, 137 N.t. 826 (1922).

This has frequently been said, also by text writers. EDwanos, CovveyANCING (5th ed. 1922) 167 reads as follows: "But a mere power of apnointment must be distinguished, in this respect, from a trust or duty, to be carried out by a person by means of a power vested in him-as where land or money is given to the children of a person, in such shares as he shall appoint, and there is no gift to the children in default of appointment. Such a power as this is called a power imperative, or (more usually) a power in the nature of a trust."

1 ReEves, ReAL Property (1909) § 333: "That is, a power in trust, in its essential nature, places upon the donee thereof a duty to esecute it, and thereby to dispose of property, in favor of some person or persons other than himself." Other texts which declare that a power in trust is imperative are: 3 Podieroy, EQUity JURISPRUDENCE (4th ed. 1918) $\S 1002$; LEAKE, Property IN LAND (2d ed. 1909) § 308; 1 PERRY, TrUSts (6th ed. 1911) § 248; 1 Tiffany, REAL Property (2d ed. 1920) § 317. 
generally does involve discretionary elements. The donee may have the privilege of deciding the size of the shares, the members from the class who will take, and the time when he will exercise the power. But if he is under a duty to exercise it at some time and under some conditions, then it may properly be said to be imperative.

On the other hand, if the donor of the power makes it optional with the donee whether he exercise the power or not, it is not a power in trust. ${ }^{6}$ An example of that type of power is found in the recent case of In re Combe. There, property was put in trust for the testator's son "and from and after his death in trust for such person or persons as my said son shall by will appoint, but I direct that such appointment must be confined to any relation or relations of the whole blood." The son desired to release the power and wished to know whether there would be an intestacy as to the remainder after his death. The court held that there would. "Am I able, from this language, to say," observed the court, "that in fact the testator has created for a certain class of persons a trust and that there was a duty on the son to execute that trust and that, if he failed to execute it, the court would execute it, and hold that the members of the class took equally between them?"

While the notion that a power in trust is imperative seems well enough established, two other conceptions of the term deserve mention. In a learned article in the Harvard Law Review ${ }^{8}$ Professor Gray defined a power in trust as "a power which imposes upon the donee a duty to exercise it, enforceable in equity." In the course of his discussion he took the position that only powers appendant are enforceable in equity, and that, therefore, they only are properly termed powers in trust. ${ }^{2}$ But in effect Professor Gray appears to have conceded that the term power in trust is commonly applied by the courts to powers which are not appendant. And, in fact, most of his discussion is directed to the legal consequences of the donee's failure to exercise the power, a subject which will be considered later.

\footnotetext{
${ }^{5}$ Supra note 4, at 569.

6 Brook v. Brook, supra note 4.

7 Supra note 4.

8 Gray, Powers in Trust and Gifts Implied in Default of Appointments (1911) 25 HARV. L. REv. 1.

9 The following statement from 23 Halsbury, LAws of ENGLAND (1912) 69, is in accord with Professor Gray's view:

"The distinction between trusts and powers is that, while the court will compel the execution of a trust, it cannot compel the execution of a powor; but there are powers which in their nature are fiduciary, in the sense that the donee of the power is a trustee for the exercise of the power, and has an interest extensive enough to allow of its exercise, and in these cases the court does not allow the non-execution of the power to defeat the intention of the donor."
} 
It should also be observed that under the statutory system of powers in effect in New York ${ }^{19}$ and a few other states, a power in trust is not necessarily imperative. Mrr. Rood, apparently influenced by such statutory definitions, in the recent edition of his text on Wills, defines a power in trust as follows: :12 $^{2}$

"Trust powers are those in which the person having the power, though not necessarily bound to exercise it, nor necessarily having any title to the property, cannot lawfully appoint himself or appropriate to himself the proceeds of the exercise of the power, but has merely a duty to exercise a discretion as to whether and if so how to appoint or convey for the benefit of others."

The decision in the case of In re Combc, already referred to, is inconsistent with MIr. Rood's definition. He cites no authority for it, and it is believed that, outside those jurisdictions having statutory systems of powers, the decisions do not sustain his position. As an exposition of statutory powers in trust is beyond the scope of this paper, it will be assumed that statutory systems of powers are excluded from the further course of this discussion.

However, merely to say that the distinguishing mark of a power in trust is its imperative character is of small importance. The significant question is: What legal consequences arise from the fact that a power is imperative? Suppose the donee of a power refuses to exercise it or dies without exercising it. If the power is not in trust, obviously nothing can be done about the donee's omission. He has the privilege of refusing to exercise the power. Hence, no one has a right to compel him to

${ }^{10}$ N. Y. Cons. Laws (Cahill, 1923) c. 51 on Real Property Law, includes the following sections:

"Sec. 137. GeNERAL Power IN TruST. A general power is in trust where any person or class of persons, other than the grantee of the power, is designated as entitled to the proceeds, or any portion of the procecds, or other benefits to result from its execution.

"Sec. 138. Speclal Power IN Trust. A special power is in trust where either,

1. The disposition or charge which it authorizes is limited to be made to a person or class of persons, other than the grantee of the power; or

2. A person or class of persons, other than the grantee, is designated as entitled to any benefits, from the disposition or charge authorized by the power.

"Sec. 157. When a Trust Power Is Imrperative. A trust power, unless its execution or non-execution is made expressly to depend on the will of the grantee, is imperative, and imposes a duty on the grantee, the performance of which may be compelled for the benefit of the perion interested. A trust power does not cease to be imperative where the grantee has the right to select any, and exclude others, of the perzons designated as the beneficiaries of the trust."

${ }^{11}$ Roop, WILLS (2d ed. 1926) $\$ 758$ j. 
exercise it. But if it be a power in trust, then the creator of the power has intended to impose a duty on the donee to exercise it. And the question is: What remedies, if any, does the law provide for the enforcement of the donee's duty? That courts have attempted to do something in the direction of carrying out the donor's wishes does not admit of doubt. Take, for example, the typical case (already suggested by the discussion of Millhollen's Adm'r v. Rice) where property is given to $A$ for life and $A$ is directed to appoint the fee among the children of $B$ in such shares as he may determine. If $A$ dies without exercising the power, the children of $B$ are regularly given the property in equal shares. Three theories have been advanced to explain this result: first, that the donee of the power is a trustee, the power itself being the trust res, and the class of possible appoint-

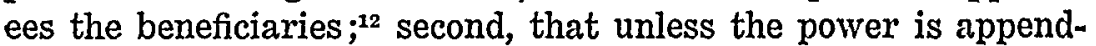
ant, equity will do nothing toward enforcing the exercise of the power, but that, purely as a matter of construction, a gift in default of appointment will regularly be implied in favor of the class of possible objects of the power; and, third, that if the donee dies without exercising the power, a constructive trust will . attach to the property in favor of the objects of the power.

With reference to the first theory to the effect that the power itself is a trust res, objection may be made upon the ground that a prime essential to a trust is that specific property must constitute its subject matter. If one is inclined to be over technical, such an objection must inevitably be sustained. It is true, the usual view of the courts is that a power is not property. ${ }^{13}$ But equity has recognized some other rather tenuous legal relations as constituting a sufficient res to create a trust, ${ }^{14}$ and it is difficult to see why the doctrines of trusts could not be extended to apply to such a trust res as this. However, even if we apply the analogy of trusts, our difficulties do not end. If the

12 See Bogert, Trusts (1921) 35: "A power in trust is a trust in which the trust res is a power to dispose of property; ..." And at 36: "Tho donee of a power in trust is a trustee."

See also POMIERoY, loc. cit. supra note 4: "Analogous to trusts proper, but differing from them in one essential feature, are powers in trust. In a true trust the legal title is in and by its creation always vested in tho trustee, but to be held for the benefit of the beneficiary. . . Where the power is in trust, A may have some discretion with respect to the mode in which he shall exercise it .. . but he has no discretion as to whether ho will or will not exercise it at all. It partakes so much of the nature of a trust, that an obligation rests upon him, and an equitable right is held by the beneficiaries,- a right which equity recognizes and to a certain extent protects; so that if $\mathbf{A}$ does not discharge the duty resting upon him, a court will, to a certain extent, discharge the duty in his stead."

13 Ex parte Gilchrist, 17 Q. B. D. 521 (1886); 1 TIFFANY, op. cit. supra note 4, § 310; (1908) 8 CoL. L. REv. 652.

14 (1927) 36 YALE LAW JOURNAL 394. 
power is a trust res, it has peculiarities of its own which make it difficult for equity to aid directly in cases of non-execution. In the first place, though the power in trust be imperative, there are usually discretionary elements. As a rule, the donee has the option of exercising it at any time during his life; and all that the donor intended is that he must exercise it at some time or other. Hence, until he dies, the donee has never violated his duty, and there is nothing for which he can be sued. ${ }^{15}$ This aspect is not peculiar to a power unaccompanied by property. If the donee had the title in fee, equity would still refuse to exercise the power if it were discretionary. Second, most powers are intended to be purely personal to the donee; that is, they are to be exercised by him personally and by no one else; hence, they are intended to terminate on his death. ${ }^{13}$ Now it seems clear that a power will last no longer than the donor intended it to last. Consequently, in some cases, after the donee is dead, the power has terminated. While equity may produce a result similar to that intended by the donor, in such cases the court can hardly be said to exercise the power. Thus, even if we say that the donee is a trustee of the power, we still must conclude that in effectuating the purpose of the trust, equity will have to proceed in a different manner from that in the case of the enforcement of ordinary trust duties not involving powers. In other words, the donee of a power in trust is a unique kind of fiduciary; whether we do or do not call him a trustee will make little difference in the solution of the problems involving such powers. We still have the unanswered question: What remedies does the law provide for the non-execution of the power?

The second theory is that advanced by Professor Gray. He states his view in these words: ${ }^{17}$

"When a legal estate is given to A for life, and a power is given to $A$ or to $B$ to appoint the remainder, if the objects of

15 While there are occasional remarks indicating the contrary, the later decisions are to the effect that, whether it be a trust or a power, equity does not exercise a discretion given to the trustee or donee. See Farwitr, Powers (3d ed. 1916) 53, 54; Sugden, Powers (8th ed. 1861) 601; Gray, op. cit. supra note 8 , at 4 .

There are, however, occasional statements which imply that the court is exercising the power. See In re Phene's Trusts, L.R. 5 Eq. 846, 348 (1868), where the court observes: "The court is performing the office of executors and must give it to the same persons."

16 Of course, whether a power is personal or not, or whether it is intended to attach to the office for the time being, is a matter of construction. And it must further be recognized that at the present time the rule as to the survival of some types of powers is modified by statute. On the construction of powers with reference to their survival, see KALES, FUTURE INTERESTS (2d ed. 1920) \$§ 624-633.

17 Gray, op. cit. supra note 8, at 3. 
the power take in default of appointment, they must take by an implied gift; equity has nothing to do with it."

He then points out, ${ }^{18}$ quoting from Lord St. Leonards, that in Brown v. Higgs, Lord Eldon, in laying down a general principle concerning powers in trust, qualified that principle by limiting it to cases where the testator has given the donee an interest in the property sufficient to enable him to discharge the duty imposed by the will. That is, if, in the exercise of the power, the donee will only affect property interests to which he has title, we may call it a power in trust, and equity will effectuate it by attaching a trust to the property for the benefit of the objects of the power. But if his power is in gross or purely collateral, that is, if some one else has title to the property over which the power is to be exercised, equity will not aid in enforcing the duty the testator has imposed upon the donee. Professor Gray then states the rule as follows:

"When a special power in gross or simply collateral to appoint to a class is given, and there is no gift over in default of appointment, and no appointment is made, the objects of the power take by implication the estate or interest that might have been appointed to them."

No doubt Professor Gray was correct in saying that equity does not exercise a discretion, and that, therefore, equity would not exercise a power. But it does not necessarily follow that "equity has nothing to do with it." Some other equitable remedy may be possible even though the court will not exercise the power.

Such a remedy is suggested in the constructive trust theory, which was put forward by the late Professor Albert M. Kales.10 His view was that if the donee of such a power in trust died without executing it, the class of persons from whom the appointmen was to be made would take the property by way of a constructive trust which was imposed upon the property in the hands of those to whom it had come by default of appointment;

${ }^{18} \mathrm{Mr}$. Gray's language is as follows: "It was the acute mind of Lord St. Leonards which first perceived that when the objects of a power take upon failure to appoint, they take by an implied gift. In the first edition of his book on Powers published in 1808, he said: 'In Brown v. Higgs, 8 Ves. 574, Lord Eldon stated the principle in all cases on this subject to be, that if the power is a power which it is the duty of the party to execute, made his duty by the requisition of the will put upon him as such by the testator, who has given him an interest extensive enough to enable him to discharge it, he is a trustee for the exercise of the power.' The important words here are 'who has given him an interest extensive enough to enable him to discharge it,' and that Lord St. Leonards thought so is shown by the fact that in later editions of the book these words are printed in italics."

19 KALES, op. cit. supra note 16, § 637. 
and that when equity distributed it equally to the members of the class, equity was enforcing a trust which arose from the failure of the donee to do his duty. The trust is called constructive because the creator of the power did not intend to create the trust. Equity simply imposes a remedy in view of the impossibility of the beneficiaries taking in the precise manner intended; and the unjust enrichment of the donor's heir, or other person into whose hands the property may have come, is sufficient justification for equity imposing the trust.

It is believed that this last theory presents the most satisfactory solution of the problem of the non-execution of powers in trust. That this view is preferable to the inplied gift doctrine may perhaps best be considered by comparing the two theories.

First, however, something of a digression is advisable to consider one type of power in trust to which the constructive trust theory is clearly applicable, namely, the power of an executor, created by the will, to sell land for the payment of debts and legacies.

Before the Statutes of Uses and of Wills, there were certain localities in England in which devises of legal interests in land were permitted by custom. In those localities, so Littleton tells us, ${ }^{20}$ a testator might provide in his will that his executor should have a power to sell his land to distribute for his soul. This was not a devise of the land to the executor. It only gave him a power. But it was a power which it was his duty to exercise. It must be remembered, of course, that at that time an executor had no authority to sell land to pay debts and legacies unless a testator so provided; the land passed directly to the heir or devisee. By the passing of the Statute of Wills in 1540, it became possible for any testator to create such a power in his executor, since lands then became generally devisable. Such a power has been called a common law power, since it existed at common law and before the Statutes of Uses and of Wills. Yet it may be doubted whether there is any reason today for distinguishing between such a power and a power operating by way of a shifting use or executory devise. Certainly a wills statute is essential to the exercise of such a power in this country. And its operation would seem to be substantially like a power operating by way of executory devise.

It is clear that the common law power of sale of an executor has always been regarded as a power in trust."1 Lord Colie speaks of such a power as a "bare trust" and as a "trust or authority." 22 Mr. Justice Bigelow, in the case of Grecnough 2 .

20 LitTtLeton, TenuRes $\$ * 169$.

217 HOLDSWORTH, HISTORY OF ENGLish LAv (1920) 171, 172, outlincs its early development.

22 Co. LITT. $\S \S \approx 113$ a, and $* 181 b$. 
Welles, ${ }^{23}$ stated the attitude of the courts toward such powers as these in the following language:

"But there is a clear and well defined distinction between a mere power, when the act is left to the will of the party to whom it is given, and powers in the nature of trusts. In cases of the latter class, the rights and interests of third parties, who are beneficially interested in the trusts which arise and grow out of the execution of the power, come in, and can be enforced as against the party to whom the power is given. Mere powers are never imperative; trusts are always imperative and obligatory upon the conscience of the party intrusted. When a trust is to be effected by the execution of a power, then the trust and power become blended and binding upon the donee of the power. The most familiar instance given in the books of such a union, is the case where a power is given by a will to sell an estate with directions to apply the proceeds upon trusts. The power is then in the nature of a trust."

As early as the seventeenth century we find a line of English cases in which it is said that equity may fasten a trust on the heir, where a testator directed his executor to sell lands. ${ }^{24}$

In Yates v. Compton, ${ }^{25}$ the testator provided in his will that his executors should sell his land and purchase an annuity of one hundred pounds per annum for the life of Jane Styles out of which she should also maintain her children, and gave thirty pounds for each child to be raised out of this annuity and his personal estate. $B$ and $C$, the executors, renounced the office. Jane Styles also died soon after the testator. Action being brought by the administrator with the will annexed of the testator's estate, who was also administrator of the estate of Jane Styles, to compel the heir to join in a sale, the Chancellor decreed the land to be sold to provide for the children's legacies. The same doctrine has been recognized in American cases. ${ }^{20}$

${ }^{23}$ Supra note 4, at 576.

24 Garfoot v. Garfoot, 1 Chan. Cas. 35 (1663); Asby v. Doyl, 1 Chan. Cas. 180. And see Locton v. Locton, 2 Freeman Ch. 136 (1637) ; Pitt v. Pelham, 2 Freeman Ch. 134 (1670).

See also Butler and Hargrave's note to Co. LrTr. $\S * 113$ a, where the following language occurs, in connection with the discussion of an executor's power to sell land: "This has long been the practice of our courts of equity; these rightly deeming the purpose for which the testator directs the money arising from the sale to be applied, to be the substantial part of the devise, and the persons named to execute the power of selling to be mere trustees; which brings the case within the general rule of equity, that a trust shall never fail of execution for want of a trustee, and that if one is wanting the court shall execute the office. The relief is administered by considering the land in whatever person vested, as bound by the trust, and compelling the heir, or other person having the legal estate, to perform it."

252 P. Wms. 308 (1725).

26 Greenough v. Welles, supra note 4; Cady v. Lincoln, supra note 4; Stoughton v. Liscomb, supra note 4; see Compton v. McMahan, 19 Mo. App. 494, 510 (1885). 
And it appears that equity does not necessarily order the heir to act, but the court may proceed to malre the sale by its own order. In Cady v. Lincoln, a comparatively recent MIississippi case involving a power of sale by an executor, (though not primarily to pay debts and legacies) the testator left the residue of the property to be sold by his executor, the proceeds to be applied to the payment of debts, and the residue to be held by the executor on certain specified trusts for the testator's children. The executor died without selling the land. The interested parties filed a bill to have the land sold, and this was done by a commissioner in chancery. This case involves the validity of the sale, the court holding it valid. The court pointed out that the executor took no title to the lands, and then observed:

"Bell, the executor, never sold the property, never exercised the trust confided in him, and, in view of the proposition that equity will never permit a trust to fail for want of a trustee, the trust still existed. But his trust was not in the property itself-that is, the land-but the proceeds of the sale. . . The beneficiaries had a right to have the property sold, not only for the purpose of partition, but under the express direction of the will. The direction as to selling was mandatory; it was necessary to sell in order to execute the trust."

It should be remarked that so far as cases involving the powers of executors to-day are concerned, the rule discussed has little practical significance. An executor or administrator may now sell to pay debts under statutory powers. And in some jurisdictions such a power is, by statute, made to survive the executor's death. But the principle laid down in these cases, that equity will effectuate the purpose of an imperative power by means of a constructive trust, is believed to be applicable to other powers, including powers of appointment. MIoreorer, these decisions on the powers of an executor clearly indicate that there are powers in trust which are not appendant, and that equity provides a remedy for their non-execution. Even Lord St. Leonards, who is cited for the proposition that properly spealing only powers appendant are powers in trust, has no hesitation in classifying as a power in trust the power of an executor created by the will.2s

To return to a comparison of the constructive trust theory with the implied gift theory, perhaps the most serious objection to the latter is the inherent difficulty, as a matter of construction, in reading any such limitation into a will or settlement. The whole notion of a power of the kind we are here considering is that it is imperative; in other words, that the donor intended

27 Supra note 4.

28 SUGDEN, op. cit. supra note 15 , at $588,589$. 
that the donee at some time should exercise the power and gave him no option as to whether or not he should exercise it. Now if we are construing the donor's intent, it is hard to infer any gift in default of appointment when the donor did not contemplate any default in the appointment. Indeeed, the case where the power is imperative is exactly the situation in which we would not expect the donor to intend a gift over in default of appointment. To put an extreme case: suppose the testator says: "I give Blackacre to $X$ for life and direct that he appoint the remainder to such one or more of his children as he sees fit. I make no provision in case he fails to appoint because I impose a duty on him to do so and expect him to fulfill it." It would seem that under no theory of implying a testator's intention could the children of $X$ take if $X$ failed to appoint, for we cannot construe a will contrary to an expressed intention. If the children of $X$ take in that case, they take by constructive trust. Yet certainly it seems as desirable to allow the children to take in this case as in a case where the testator had not made the power imperative.

Another aspect of the cases which militates against the implied gift theory is this. The rule has been frequently laid down that only those members of the class take who might have taken by an appointment had one been made. ${ }^{20}$ For example, if there is a devise to $A$ for life, with a direction to $A$ to appoint the remainder by will to such of his children as he may select, the question may arise whether the children of $A$ who predecease him will be entitled to share in a distribution to the children as a class when $A$ dies without making an appointment. In such a case the property has been distributed equally to those children who survived the donee of the power. Now, if equity is merely trying to carry out as far as possible the wishes of the testator by means of a constructive trust, that result seems reasonable. But it appears to make an exceedingly forced construction of the testator's intent to say that he intended a gift in default of appointment which is not vested. For it must be remembered that since the decision in Doe d. Willis v. Martin ${ }^{30}$ a remainder in default of appointment is vested, in the absence of elements which would make it contingent. Now, if the gift in default of appointment is not vested, then the testator may not have dis-

${ }^{29}$ Lambert v. Thwaites, L.R. 2 Eq. 151 (1866); Moore v. Ffolliot, L.R. Ir. 19 Ch. Div. 499 (1887); Stolworthy v. Sancroft, 33 L.J. Ch. 708 (1864); In re Phene's Trusts, supra note 15; Walsh v. Wallinger, 2 Russ. \& My. 78 (1830); Re White's Trusts, Johns. 656 (1860); Halfhead v. Shepherd, 28 L.J.Q.B. 248 (1859). See also Connell v. Cole, 89 Ala. 381, 8 So. 72 (1890); Sugden, op. cit. supra note 15, at 595, 596. But see Cruse, Adm'r v. MIcKee, 2 Head 1 (Tenn. 1858).

304 Term R. 39 (1790). 
posed of the whole fee. Thus the argument so often made that a provision is implied in a will because the testator did not intend to die intestate would not apply with the same force to an implication of a contingent gift in default, as to a vested gift in default. Of course, it is entirely possible to imply a contingent gift in default of appointment, if there is language in the will to show such an intent. But to imply such a gift as a general rule looks very much as if the court were making a will for the testator.

Another aspect of the decisions which lends itself more readily to the constructive trust theory is involved in the rule that, in the absence of an appointment, there may be a distribution to the class even though there is a residuary clause. ${ }^{31}$ It is conceded, of course, that if there is an express gift in default of appointment, there can be no implied gift.s2 There would likewise be no constructive trust, for if the testator made a gift in default of appointment, he would hardly intend an imperative power; besides, equity would not impose a trust which would defeat the express gift. But if there is merely a residuary clause, that in itself does not prevent a distribution to the class in a case where no appointment has been made. Now the existence of a residuary clause is not inconsistent with the recognition of a constructive trust for the class. But if we say the class talie by implied gift, we are cutting down the size of an express gift of the residue; and we are not making the implication to prevent intestacy, for the residuary clause prevents an intestacy whether a gift in default is implied or not.

The next question to be asked is: To what extent is the proposed analysis sustained by the decisions? It must be conceded that, with the exception of the cases involving powers of sale of executors, the language of the courts is not such as to indicate undeniably that the court is imposing a trust, nor is the term "constructive trust" used. ${ }^{33}$ Miost of the cases leave us

31 Rogers v. Rogers, 2 Head 660 (Tenn. 1859); In re Brierley, supro note 4.

32 See FARWELL, op. cit. supra note 15, at 533.

33 See, however, Little v. Neil, 10 W'kly Rep. 592 (1862), where the court, in declaring an equal distribution to a class on refusal of the trustees to appoint, remarked: "but under the present circumstances the court was not exercising the discretion of the trustees nor construing the settlement."

See also Hazard v. Bacon, 42 R. I. 415, 419, 108 Atl. 499, 501 (1920), where, on the death of the trustees without exercising the power, the court ordered an equal distribution, observing that though the court could not exereise the discretion of the original trustee, it would not permit the general intention of the testator to fail, "but will order a division of the trust estate among the members of the class, for whose benefit the trust estate was created, in accordance with the most equitable rule, which in this case is that of equality." 
somewhat in doubt as to the precise theory on which the property is being distributed in lieu of an appointment. Quite often the language is of such a character as to make it impossible to tell whether the court is talking about a gift by implication of a trust. For example, in the case of In re Weekes' Settlement, ${ }^{\text {, }}$ the court, after considering whether it was a "mere power" and not "one coupled with a trust that he was bound to exercise," concluded that it was not a power in trust and said: "I hold that in this case there was no gift by implication."

In some of the cases where the donee was given the legal title to the property, the courts have talked about powers in trust, but the real problem was simply whether the donee was given the property absolutely or whether he held it in trust. ${ }^{35}$ For example, the testator devises to $A$ in fee, but expresses a desire that $A$ may distribute the property on his death to the testator's relations. If these words are imperative, there is a trust; if not, the words are mere surplusage, and $A$ takes an absolute fee without any duty in respect to it. Those cases resemble the ones we have discussed in that, if the direction is imperative, equity will aid in enforcing the duty imposed. However, there is no dispute as to the rule to be applied in those cases.

A second group of cases about which there is no dispute, and in which powers in trust are sometimes discussed, involves the following type of situation. The testator devises to $X$ in trust for the children of $Y$ with a power in $X$ to determine the shares which the children of $Y$ shall take. Here the children of $Y$ have a vested gift subject to a power. If $X$ fails to make the appointment, the children of $Y$ take, not by implication, and not by constructive trust, but by direct gift. ${ }^{36}$

In most of the cases which involve powers in trust, nothing is made of the fact that the donee may or may not have had a legal title which would be affected by the discharge of the power. In Milhollen's Adm'r v. Rice, already referred to, ${ }^{37}$ the court discussed the point in these words :

\footnotetext{
${ }^{34}$ Supra note 4. Another typical statement in which the two ideas aro blended is the following from Williams, ExECuTors (10th ed. 1905) 878: "In order to imply a gift there must be a clear indication in the will that the testator intended the power to be regarded as in the nature of a trust, so that the class or some of the class should take."

It should be noted, however that Gray and Sugden clearly differentiated the two ideas.

${ }^{35}$ Examples of this kind of problem are found in Harding v. Glyn, 1 Atk. 469 (1739) ; Pierson v. Garnett, 2 Bro. C.C. 38 (1786); Brook v. Brook, supra note 4.

36 Such appears to have been the situation in the following cases: Millikin v. Welliver, 37 Ohio St. 460 (1882); Lambert v. Thwaites, supra note 29; In re Hughes [1921] 2 Ch. 208.

${ }^{37}$ Supra note 3 , at 565 .
} 
"It is always sufficient that the donee of such a power has a life interest in the power [property (?)] he is thus authorized to dispose of in fee simple among a definite class, in order that such a power may be held to be a power in the nature of a trust. The fact, that the donee of such a power has not a fee simple interest, but is only a tenant for life, will not affect the construction of the power, or prevent it from being regarded as a power in the nature of a trust."

In Dominick v. Sayre, ${ }^{38}$ a New York case decided in 1850 , after the statutory system of powers was enacted in that state, but involving limitations created before the statutes went into effect, and to which, therefore, the statutes were inapplicable, the facts were as follows. The testator gave eight lots of land to his daughter for life, with "power to give the same by deed or will to any of the male descendants of my family of the name of Dominick." In an action to determine whether the property, on default of appointment, went to the residuary devisees on the death of the donee, or to the class, the court decreed a distribution to the class as the beneficiaries of a power in trust. In the opinion the decision of Lord Cottenham in Burrough v. Philcon so was referred to with approval, the court observing that:

"It is immaterial in whom the fee is vested at the time the power is to be executed, if the persons to whom the property is to be or may be given by an executor of the power are designated with sufficient certainty. There is then a trust in their favor."

\section{The court further remarked that:}

"A power, when the disposition which it authorizes is limited to a particular class, unless its execution is made in terms to depend upon the mere discretion of the grantee, always creates a reasonable presumption that the grantor means that it shall be executed, and his intention thus ascertained, a court of equity is bound to effectuate by construing the power as imperative."

Most of the other American cases are rather inconclusive on the aspects of the question so far considered. In some the language is that of implied gift; in some, that of powers in trust, and in others the two ideas are confused. ${ }^{10}$ None, however,

\footnotetext{
38 Supra note 4.

39 Supra note 4.

40 In the following cases, in addition to the two discussed, the decision is in the language of imperative power, or power in trust. Withers $v$. Yeadon, 1 Rich. Eq. 324 (S.C. 1845), where, however, the court expressed the view that a power in trust must be coupled with a property interest suficient to enable the donee to discharge it; Wetmore v. Henry, $259 \mathrm{Mll} .80$, 102 N.E. 189 (1913).
}

In the following, the language of implied gift is used. Loosing v. Loos- 
are necessarily inconsistent with the position herein taken; nor is there any denial, in the cases not involving statutory systems of powers, of the proposition that a power in trust is always imperative.

The English cases are more numerous. In the leading English case of Brown v. Higgs, from which quotation has already been made, ${ }^{41}$. the court without doubt proceeded on the theory that it was dealing with an imperative power, and the language of Lord Eldon in that decision has been quoted with approval time after time. In that case, however, the donee of the power had the legal title. Hence, the facts in that case would not present a situation where the power in trust theory would be put to the crucial test.

In Burrough v. Philcox, the testator gave certain real and personal estate in fee in trust with life interests to his son and daughter and gifts over to their issue; he then provided that if both children should die without leaving lawful issue the survivor should have the power to dispose by will of the property among the testator's nephews and nieces or their children. The son and daughter having both died without children, and no appointment having been made, Lord Cottingham held that the nephews and nieces and their children would take the unappointed property as a class. He concluded that the power was imperative and observed:

"Much argument was urged at the bar upon the ground that the donee of the power had no estate in the property under the will beyond a life interest. In my view of the case this is quite immaterial. It is not, certainly, one of those cases in which property is given, with expressions added, as to the disposal of it, which are held to fix a trust upon the gift; but the whole is given to trustees, and the question is whether there be found in the will a sufficient declaration of who, in the events which have happened, are to be the cestuis que trust; and if that be sufficiently expressed, it is immaterial whether the donee of the power be also a trustee, or whether the trust be vested in others."

In the case of In re Weekes' Settlement,"2 so severely criticised by Professor Gray, the facts were as follows. By a marriage settlement E.W. Was given a general power to appoint by will,

ing, 85 Neb. 66, 122 N.W. 707 (1909); McGaughey's Adm'r v. Henry, 15 B. Mon. 383 (Ky. 1854); Rogers v. Rogers, supra note 31. In the latter case the court referred to the power in trust doctrine, but finally based its decision on implied gift. In Tomlinson v. Nickell, 24 W. Va. 148 (1884), language of power in trust and of implied gift seem to be used interchangeably. In Varrel v. Wendell, $20 \mathrm{~N}$. H. 431 (1846), the court's theory as to this aspect of the case does not clearly appear. The same may be said of Pitts v. Howard, 208 Ala. 380, 94 So. 495 (1922).

\&x Supra note 5 .

42 Supra note 4. 
and in default of appointment, the property was to go to the persons who would be entitled to take by descent if E.W. died intestate and a widow. E.W. appointed a life interest to her husband together with "the power to dispose of all such property by will amongst our children in accordance with the power granted to him as regards the other property which I have under my marriage settlements." The husband died without exercising the power given him by his wife's will. The court refused to hold that the children would take. Romer, J., in his opinion, clearly shows that the class would not take in this lind of case unless the power were imperative. He says:

"The authorities do not show in my opinion, that there is a hard and fast rule that a gift to $A$ for life with a nower to $A$ to appoint among a class and nothing more, must, if there is no gift over in the will, be held a gift by implication to the class in default of the power being exercised. In my opinion the cases show (though there may be found here and there certain remarks of a few learned judges which, if not interpreted by the facts of the particular case before them, might seem to have a more extended operation) that you must find in the will an indication that the testatrix did intend the class or some of the class to take-intended that the power should be regarded in the nature of a trust-only a power of selection being given, as, for example, a gift to $A$ for life with gift over to such of a class as $A$ shall appoint."

Following In re Weeles' Settlement is the case of In re Combe, ${ }^{43}$ already referred to, which clearly lays down the rule that the power must be imperative if the property is to go to the class on failure of the donee to appoint.

In Moore v. Ffolliot, ${ }^{44}$ (an earlier case), however, we find a repudiation of the power in trust idea as applied to collateral powers and powers in gross. In the course of its discussion, the court stated that in a case of that sort, if the members of the class took at all, they would take by implication.5 The facts of that case, however, can be explained quite as well on a theory of constructive trust as on any other. Property had been left to the testator's three nieces for life with a power to appoint

${ }^{13}$ Supra note 4.

14 Supra note 29.

45 The language is as follows: "There is, however, a distinct class of cases where the donee of the power takes not more than a life estate. In these, however clear the expression of desire on the part of the donee in favor of a particular person or class of persons may be, yet as the donee has no estate, or none beyond his life, the trust to exercise the power is as such personal, and does not directly attach upon the inheritance, save in so far as the court finds in the language an implication in favor of the objects of the power in default of appointment. In this case if they talie the estate they take it by implication, and thus by way of limitation under the instrument creating the power." 
by will to the testator's grandnephew if he conducted himself properly. The grandnephew predeceased two of the nieces, and no appointment was made. The court simply decided that, though there might have been an implied gift to the grandnephew if he had survived, there was none under the circumstances which had transpired.

It must be conceded that many English cases purport to be decided on a doctrine of implied gift. In practically all these cases, however, the court was dealing with property which was in trust pending the appointment. In such a case the process of giving relief would be identical whether the implied gift theory or the constructive trust theory were applied. Suppose a testator devises Blackacre to $T$ in fee in trust for $A$ for life and then directs $A$ to appoint the beneficiaries in remainder from among his children, and $A$ dies without so appointing. If equity imposes a constructive trust in favor of the children it will be imposed upon $T$. If there is an implied gift, it is an implied equitable gift, in other words, an implied trust in favor of the children, $T$ being the trustee. It may be surmised that such a situation as this is responsible for the oft recurring observation that, because there is a power in trust, there is an implied gift.

It is believed that so far no reported case, either American or English, has been decided which tests absolutely the question whether the court is applying a trust theory or an implied gift theory. But cases could be put which would test the point. For example, suppose the usual situation: a power to appoint land to a class, which would be construed as designed to impose a duty on the donee to appoint, and the death of the donee without appointment. If the class takes by implication from the will, the members of the class could bring trespass or ejectment for the land. If their rights are equitable, they might be forced first to file a bill in equity to get the legal title. Professor Kales also suggests that if the class were to take by way of trust, their rights might be defeated by a bona fide purchaser, but if they took by implication, that could not happen. Suffice it to say, it is hard to think of a case where the land would be likely to come into the hands of a bona fide purchaser. Hence, whether one regards the class as taking by a gift in default of appointment or by a trust depends on the viewpoint which appeals to him as the more reasonable. But it seems clear that the ideas of an imperative power and of a gift by implication are utterly inconsistent.

One aspect of these decisions on powers of appointment, of a more practical character, is this: Must there be evidence of an intent to make the power imperative, or does the mere provision for a power to appoint to a definite class raise a presumption that it is imperative, in the absence of language to the contrary? Or, 
if we state it in Professor Gray's terminology: Is there an implied gift in default, in the absence of language to the contrary, merely because there is a power to appoint to the class?

As we have seen, Mrr. Gray thought there was such a fixed rule, and $\mathrm{Mr}$. Farwell was of the same opinion. ${ }^{\circ 5}$ There was, without doubt, a body of English authority supporting that view. ${ }^{47}$ On the other hand, there was a line of English cases which seems to have required something more than the mere existence of a power to appoint to the class. ${ }^{4 s}$ Then came the case of In re Weekes' Settlement, which, as we have seen, refused to lay down the hard and fast rule that a power to appoint to a definite class raises a trust for the class. The facts of that case were peculiar. The donor of the power in question created it by virtue of a general power which she had, and there was already a specific provision in default of the exercise of this general power. Thus there was, in a way, already a provision in default of appointment. It has sometimes been thought that this provision distinguishes the case from some of the earlier decisions. In his decision, Romer, J., though he pointed out that element, did not base his conclusion entirely on that fact. In the case of In re Combe, already referred to, where the limitation was to "Such person or persons as my son shall by will appoint, but I direct that such appointment must be confined to any relation or relations of mine of the whole blood," the court followed the doctrine of In re Weckes' Settlemcat and refused to find a power in trust. These cases, it is believed, mark a departure in the English law. Whether a power to appoint to the children of $X$ is a power in trust is a question of fact. The court would quite likely determine that such a power was imperative, in the absence of anything indicating a contrary intent, but it is believed that there is no rule of law to that effect.99

${ }^{46}$ FARWELL, op. cit supra note 15 , at 528.

47 Such a rule was announced in Kennedy v. Kingston, 2 Jac. \& W. 480 (1821) ; Lambert v. Thwaites, supra note 29; Wilson v. Duguid, 24 Ch. D. 244 (1883) ; Stolworthy v. Sancroft, supra note 29.

48 Duke of MTarlborough v. Godolphin, 2 Ves. Sr. 61 (1750); Healy v. Donnery, 3 Ir. Com. L. Rep. 213 (1853); In re Hall, supra note 4; Carberry v. MIcCarthy, L. R. Ir. 7 Ch. Div. 328 (1881).

19 See In re Llewellyn's Settlement, supra note 4, which involved a settlement by which property was given in trust on the death of the survivor of the husband and wife, to pay over to such child or children or their isaue, and in such shares as the wife by deed or will should appoint, to be payable to such child or children on attaining the age of twenty-one, or if a daughter, marrying within that age with consent. The wife having died without exercising the power, it was held that the property went to children and grandchildren equally. The court, after reviewing the earlier authorities and expressing its approval of the rulc laid down in the Weelses' Scttlement case, observed that if the learned judge who decided that case had 
May it not be that the same sort of change of view point in the construction of powers in trust is indicated by these cases, as took place at a much earlier period in the construction of socalled precatory trusts? It will be recalled that at one time very slight language of desire or request on the part of a testator was sufficient to impose a trust upon a devisee. In the same way in the case of powers in trust, the courts once regarded the power as imperative without much evidence of any such intent on the part of the testator; but these recent English cases show a departure from that viewpoint.

Among the American cases, we find two of the best reasoned decisions laying down the rule that there is a presumption that a special power to appoint to a class is imperative. ${ }^{50}$ In two instances, where there was no appointment, courts have refused to make a gift to the class under circumstances which would indicate that they were not following such a presumption, though there is not argument to that effect." Whether the American courts would follow In re Combe and not apply any presumption as to the imperative character of the power is believed to be, to a large extent, an open question.

Having considered at length the remedy afforded when the donee of a power in trust dies without executing it, we may ask the question: Will equity do anything to compel the donee to do his duty while he is yet alive? We are here, of course, confronted with the difficulty which has already been referred to, that though the power is imperative, the donee usually has a discretion as to the time he will exercise it, and equity will not interfere with that discretion. Suppose, however, the donee is to exercise the power within a given time or within a reasonable time and that time has expired. Will equity order him to exer. cise the power? In the case of the power of sale of an executor, at least, it seems that this remedy would be available."2 There are frequent statements to that effect, but very little authority on the point. If equity would do so in the case of a power of sale, there seems to be no good reason why it would not do so in other cases of imperative powers, if a case arose where the time had arrived when the donee was required by the terms of

before him the words here considered, he would have found that there was a gift to the children by implication.

See also In re Hughes, supra note 36 , a case involving a gift in trust subject to a power, where the court quoted with approval the hard and fast rule, as stated by Farwell, making an implication of a gift.

50 Dominick v. Sayre, supra note 4; Milhollen's Adm'r v. Rice, supra note 4.

51 Morris v. Owen, 2 Call 520 (Va. 1801); Holt v. Hogan, 5 Jones Eq. 82 (N.C. 1859). See also Frazier v. Frazier's Ex'rs, 2 Leigh 642 (Va. 1831).

52 Teator v. Salander, 305 IIl. 17, 136 N.E. 873 (1922).

s3 2 Dana 74 (Ky. 1834). 
the instrument to exercise the power. In Mnuldrow's Heirs $v$. Fox's Heirs, ${ }^{53}$ it is clear that the court ordered the executor to sell at the instance of the beneficiaries, though the action does not directly involve a review of that order. In Piper $v$. Pipcr, as reference is made to an order in the court below (unappealed from and therefore not in issue in this action), directing the executor to execute a power to determine the size of shares of legatees within a given time. Under the facts of the case the action of the court may be questioned, but the case shows the tendency of courts to treat the duty of some holders of powers as enforceable in equity.

In conclusion, then, we may say that the essential feature of a power in trust is that the creator intended it to be imperative; that equity will, in so far as it can, carry out this intention of the donor; that equity will never exercise the power; but that it provides such remedies as are possible under the circumstances; as Hawkins says, "the court . . . carries out the intention of the testator cy pres"; 55 that a fair conclusion from the cases is that equity will impose a constructive trust on the property for the benefit of those for whose benefit the power was made imperative; and that in a proper case it might order the donee to make an appointment. Whether or not the power itself is to be regarded as a trust res makes little difference, since it is of such a unique character that many analogies from the law of trusts would be inapplicable. The important thing is that the donee of the power is under an active fiduciary duty of a character different from any that may be imposed on donees of optional powers.

Are there other legal consequences arising from the fact that a power is intended to be imperative, in addition to those which have already been outlined? In the main that is a question which the decisions have so far not clearly answered. Eut it is believed that on a question of the extinguishment of powers by the act of the donee, the imperative character of the power is controlling. That, however, will be considered in Part II of this paper.

(To be continued)

543 My. \& K. 159 (1834).

s5 Hawkins, Wills (3d ed. 1925) 73. 